\title{
PENGARUH GAYA MENGAJAR DITINJAU DARI PERCAYA DIRI TERHADAP HASIL BELAJAR HANDSPRING SENAM LANTAI
}

\author{
Ridwan Gumilar \\ Universitas Siliwangi \\ Ridwangumilar@unsil.ac.id
}

\begin{abstract}
Abstrak
Tujuan dari penelitian ini adalah untuk memperoleh informasi tentang pengaruh gaya mengajar ditinjau dari percaya diri terhadap hasil belajar handspring senam lantai mahasiswa PJKR Universitas Siliwangi Tasikmalaya. Teknik analisis menggunakan analisis varians (ANAVA) dua arah, diikuti oleh tes Tukey pada taraf signifikansi $\alpha=$ 0,05. Diperoleh: (1) hasil belajar handspring secara keseluruhan yang diajar dengan gaya mengajar resiprokal lebih baik daripada yang diajar dengan menggunakan gaya mengajar latihan (Fo = $4.19>\mathrm{Ft}=4.00)$; (2) ada interaksi antara gaya mengajar dengan percaya diri terhadap hasil belajar handspring senam lantai, $(\mathrm{Fo}=4.10>\mathrm{Ft}=4.00)$; (3) bagi mahasiswa yang memiliki percaya diri tinggi, hasil belajar handspring yang diajar dengan gaya mengajar resiprokal lebih baik daripada yang diajar dengan gaya mengajar latihan (qo = 4.149> qt = 3.63); (4) bagi mahasiswa yang memiliki percaya diri rendah hasil belajar handspring yang diajar dengan gaya mengajar latihan lebih baik daripada yang diajar dengan gaya mengajar resiprokal $(q 0=7.379<\mathrm{qt}=3.63)$. Diharapkan kepada seluruh dosen dan guru untuk memberikan senam lantai belajar latihan tertentu saja lebih baik menggunakan perintah gaya mengajar.
\end{abstract}

\section{Kata kunci: gaya mengajar, percaya diri, handspring senam lantai.}

\begin{abstract}
The purpose of this study was to obtain information on the effect of teaching style in terms of confidence to the learning outcomes of students PJKR floor exercise gymnastics handspring Siliwangi University of Tasikmalaya. Analysis techniques using analysis of variance ( ANOVA) and two-way, followed by the Tukey test at significance level $\alpha=$ 0.05 . Obtained : ( 1 ) the overall learning outcomes handspring taught by reciprocal teaching style better than that taught using teaching style exercise ( Fo $=4.19>F t=$ $4.00)$; ( 2 ) there is an interaction between the style of teaching with confidence for learning outcomes handspring gymnastics floor , ( Fo $=4: 10>F t=4.00) ;(3)$ for students who have high self-confidence, learning outcomes handspring taught by reciprocal teaching style better than those taught by the teaching style exercises ( qo = $4149>q t=3.63)$; ( 4 ) for students who have low confidence handspring learning outcomes are taught to practice teaching style better than that taught by reciprocal teaching style ( $q 0=7379<q t=3.63)$ Expected to all lecturers and teachers to provide learning gymnastics floor exercise better use of certain teaching style command.
\end{abstract}

Keywords : confidence, handspring, teaching style. 


\section{PENDAHULUAN}

senam dalam bahasa

Indonesia dan gymnastics (inggris) yang diambil dengan bahasa aslinya asal kata Gymnos (Yunani) yang berarti telanjang, Gymnastics sendiri diambil dari kata kerja Gymnazein artinya berlatih atau melatih diri. Adapun para ahli seperti Imam Hidayat menyatakan Gymnastiek dipakai untuk menunjukan kegiatankegiatan fisik yang memerlukan keleluasaan gerak sehingga perlu dilakukan dengan telanjang atau setengah telanjang (Hidayat,1996).

Mengikuti alur perkembangan aliran seperti dewasa ini Imam Hidayat mengemukakan bahwa "senam adalah suatu latihan tubuh yang dikontruk dengan sengaja, dilakukan secara sadar dan terencana, disusun secara sistematis dengan tujuan meningkatkan kesegaran jasmani, mengembangkan keterampilan dan menanamkan nilainilai mental spiritual"(Hidayat, 1996). Sedangkan menurut Peter H Werner Senam diartikan sebagai bentuk latihan tubuh pada lantai atau pada alat yang dirancang untuk meningkatkan daya tahan, kelentukan, kekuatan, kelincahan, koordinasi serta kontrol tubuh"(P.H werner dkk, 2012)

Uraian dari para ahli diatas intinya dapat disimpulkan tubuh bukan alatnya bukan pula geraknya pada umumnya gerak bertujuan meningkatkan kualitas fisik serta penguasaan pengontrolannya.

Artistic Gymnastics atau senam artistik adalah "Senam yang digabungkan aspek tumbling dan akrobatik untuk mendapatkan efek artistik dari gerakan-gerakan yang dilakukan pada setiap nomor atau per alat”(Hidayat, 1996)
Efek artistik dihasilkan dari Amplitudo (besaran) gerakan serta kesempurnaan gerak dalam menguasai tubuh ketika melakukan berbagai posisi dalam setiap alat yang diperlombakan. Alat yang digunakan adalah untuk putra lntai, meja lompat, palang tunggal, palang sejajar, kuda pelana dan gelanggelang, sedangkan untuk putri adalah lantai, meja lompat, palang bertingkat dan balok keseimbangan.

Senam artistik telah diberikan kepada peserta didik dari mulai Sekolah Dasar sampai sekolah Menengah Umum, karena senam merupakan salah satu komponen kompetensi dasar pada kurikulum pengajaran PENJAS. Pada umumnya hanya dua alat yang diberikan pada sekolah umum yaitu alat lantai dan meja lompat. Dari hal ini seharusnya siswa yang telah menyelesaikan pendidikan SMA atau sederajatnya mampu untuk mempraktikan keterampilan senam mengingat senam telah diberikan dari sekolah dasar hingga sekolah menengah umum.

Hasil data empiris dari kegiatan UAS mata kuliah senam yang didapat rata-rata mahasiswa Universitas Siliwangi angkatan 2013 nilainya kurang, terlebih nilai yang kurang terdapat pada nilai keterampilan Handspring dalam senam lantai.

Hal ini mungkin disebabkan oleh faktor internal dari mahasiswa itu sendiri berupa tingkat kepercayaan diri yang kurang, karena dalam melakukan gerakan senam harus didasari oleh kepercayaan diri dari pelaku.

Faktor eksternal juga sangat mempengaruhi bagi hasil kegiatan belajar mengajar, salah satu faktor eksternal adalah kurang tepatnya 
pemilihan gaya mengajar dari seorang tenaga pengajar yang menurut peserta didik atau mahasiswa kurang menarik.

Uraian di atas membuat penulis tertarik untuk mengkaji salah satu gerakan Handspring dalam senam, maka dari itu penulis mengangkat sebuah judul penelitian "Pengaruh Gaya Mengajar Ditinjau Dari Percaya Diri Terhadap Hasil Belajar Handspring Senam Lantai”. Penulis berharap dengan diadakannya penelitian ini dapat membantu para pelatih dan atlet untuk lebih memahami dan mengetahui pengaruh latihan tersebut memang terbukti kebenarannya.

\section{BAHAN DAN METODE}

Dalam keseluruhan proses pendidikan di sekolah, kegiatan belajar merupakan kegiatan yang paling utama dan pokok. Ini berarti bahwa berhasilnya pencapaian tujuan pendidikan tergantung bagaimana proses belajar yang dialami oleh siswa sebagai peserta didik.

Hilgard dan Bower dalam buku ngalim purwanto mengemukakan bahwa "belajar berhubungan dengan perubahan tingkah laku seseorang terhadap suatu situasi tertentu yang disebabkan oleh pengalamannya”(Purwanto, 2007).

Purwanto mengemukakan bahwa "hasil belajar merupakan perubahan perilaku siswa terhadap belajar"(Purwanto, 2011). Wingkel dalam buku purwanto mendefinisikan "hasil belajar adalah perubahan yang mengakibatkan manusia berubah dalam sikap dan tingkah lakunya” (Purwanto, 2011).
Senam lantai adalah salah satu bagian dari senam artistik. Senam lantai sering disebutkan suatu cabang olahraga oleh kalangan masyarakat. Agus mahendra mendefinisikan "senam lantai adalah senam yang dilakukan oleh putra /putri yang berbentuk rangkaian (rangkaian wajib atau pilihan) yang merupakan unsur wajib oleh setiap pesenam, adapun setiap pesenam putra tampil dalam waktu 70 detik dan putri 90 detik yang wajib diiringi dengan musik dengan memanfaatkan seluruh area latihan (12 m x 12 m)"(Mahendra, 2004).

$$
\text { handspring adalah }
$$

keterampilan yang sangat dinamis yang memerlukan lentingan minimal. Dimulai dari percepatan yang didapat dari hurdle (awalan untuk handspring atau round off), pesenam memulai gerakan melontarkan salah satu kakinya keatas belakang untuk mencapai fase layangan dalam posisi kurvalinier, sebelum mendarat dalam posisi berdiri(Mahendra, 2004).

formasi

Gaya mengajar dalam bentuk pengorganisasian metode pembelajaran ini disebut gaya mengajar resiprokal atau timbal balik. Susilodinata Halim dan Agus Mukholit mengatakan "Pengorganisasian gaya mengajar cara ini dilakukan secara berpasangan. Setiap anggota dari pasangan ini mempunyai peran masing-masing. Salah satu diantara mereka berperan sebagai pelaku sementara yang lainnya berperan sebagai pengamat”(Halim dan Mukholid, 1994).

Gaya mengajar latihan adalah pedoman mengajar dipergunakan oleh guru untuk menyajikan materi pelajaran dalam bentuk latihan bagian demi bagian secara berurutan. 
Di dalam gaya mengajar latihan unsur-unsur penting adalah "guru memberikan peragaan dalam mengajarkan setiap bagian materi pembelajaran secara berurutan dan siswa diberi waktu cukup untuk melakukan latihan secara berulangulang. Maka peragaan dan ulangan merupakan unsur menentukan keberhasilan siswa dalam belajar dengan gaya mengajar latihan" (Halim dan Mukholid, 1994).

Rasa percaya diri (self confidence) menurut The American Heritage Dictionary didefinisikan sebagai “consciousness of one's own powers and abilities" (kesadaran akan kekuatan dan kemampuan diri sendiri). Sementara Webster's New World Dictionary mendefinisikannya sebagai "reliance on one's own power" (bergantung pada kekuatan diri sendiri). Selain itu Longman Dictionary of Contemporary English yang menyatakan bahwa jika anda punya self confidence, anda sure that you can do things well (yakin bahwa anda bisa melakukan hal-hal dengan baik) (Wishnubroto, 2005). Sehingga percaya diri bisa disebut juga keyakinan dalam melakukan sesuatu dengan baik. Dalam kamus Psikologi juga disebutkan bahwa, percaya diri adalah kepercayaan akan kemampuan sendiri yang memadai dan menyadari kemampuannya yang dimiliki, serta dapat memanfaatkan secara tepat (Anshari, 1996) Sesuai dengan pengertian di atas, percaya diri merupakan kemampuan seseorang untuk mengetahui dan menyadari kemampuan dirinya baik berupa kekurangan maupun kelebihan yang dapat dimanfaatkan untuk aktifitas atau hal-hal yang penting secara tepat.
Metode yang digunakan dalam penelitian ini adalah metode eksperimen. Adapun disain penelitian yang digunakan adalah faktorial Treatment by Level 2 x 2 . Adapun rancangan penelitiannya seperti terlihat pada tabel 2 di bawah ini.

Tabel 1. Desain Treatment by Level 2 x 2 .

\begin{tabular}{|c|c|c|}
\hline \multirow{2}{*}{$\begin{array}{c}\text { Percaya } \\
\text { Diri }\end{array}$} & \multicolumn{2}{|c|}{ Gaya Mengajar } \\
\hline & $\begin{array}{c}\text { Resiprokal } \\
\left(\mathbf{A}_{1}\right)\end{array}$ & $\begin{array}{c}\text { Latihan } \\
\left(\mathbf{A}_{2}\right)\end{array}$ \\
\hline $\begin{array}{c}\text { Tinggi } \\
B_{1} \\
\end{array}$ & $\mathrm{~A}_{1} \mathrm{~B}_{1}$ & $\mathrm{~A}_{2} \mathrm{~B}_{1}$ \\
\hline $\begin{array}{c}\text { Rendah } \\
\text { B }_{2}\end{array}$ & $\mathrm{~A}_{1} \mathrm{~B}_{2}$ & $\mathrm{~A}_{2} \mathrm{~B}_{2}$ \\
\hline TOTAL & $\mathrm{A}_{1}$ & $\mathrm{~A}_{2}$ \\
\hline
\end{tabular}

\begin{tabular}{cccc}
\hline Keterangan : & & \\
$\mathrm{A}_{1}$ & $:$ & Gaya & Mengajar \\
Resiprokal & & & \\
$\mathrm{A}_{2}$ & $:$ & Gaya & Mengajar \\
Latihan & & &
\end{tabular}
$\mathrm{A}_{1} \mathrm{~B}_{1} \quad$ : Gaya Mengajar Resiprokal dengan Percaya Diri Tinggi

$$
\mathrm{A}_{2} \mathrm{~B}_{1} \quad \text { : Gaya Mengajar }
$$

Latihan Percaya Diri Tinggi

$$
\mathrm{A}_{1} \mathrm{~B}_{2} \quad \text { : Gaya Mengajar }
$$

Resiprokal dengan Percaya Diri Rendah

$$
\mathrm{A}_{2} \mathrm{~B}_{2} \quad \text { : Gaya Mengajar }
$$

Latihan dengan Percaya Diri Rendah

Teknik pengambilan sampel yang digunakan mengacu pada prosedur yang dinyatakan oleh Ferducci yaitu menetapkan sampel dengan teknik persentase melalui pembagian dengan sistem ranking menggunakan random sampling (acak sederhana). Instrumen penelitian yang digunakan untuk memperoleh data tentang hasil belajar handspring adalah dengan menggunakan tes keterampilan handspring yang langsung diberi nilai 
oleh juri ataupun dosen matakuliah senam lantai.

Teknik analis data yaitu menggunakan analis variansi (ANAVA) dua jalur, kemudian dilanjutkan dengan Uji Tukey. Sebelumnya harus menguji dulu persyartan analisis yakni uji normalitas dan uji homogenitas.

\section{HASIL DAN PEMBAHASAN}

Untuk menguji hipotesis, data hasil daya tahan kardiorespirasi diolah dengan menggunakan teknik analisis statistik, yaitu analisis varians (ANAVA) dua jalan. Sebelum data dianalisis, maka terlebih dahulu dilakukan uji persyaratan ANAVA, yaitu : (1) Uji normalitas, dan (2) Uji homogenitas. Uji normalitas dilakukan pada semua kelompok yang akan dibandingkan dengan menggunakan uji Lilliefors. Hasil pengujian tersebut menunjukkan bahwa harga $\mathrm{L}_{\text {hitung }}$ untuk semua kelompok lebih kecil daripada $\mathrm{L}_{\text {tabel }}$.

Tabel 2. Rangkuman Hasil Uji Normalitas Populasi

\begin{tabular}{|c|c|c|c|c|}
\hline Kelompok & $\mathbf{N}$ & $\mathbf{L}_{\text {hitung }}$ & $\begin{array}{c}\mathbf{L}_{\text {tabel }} \\
\boldsymbol{\alpha}=\mathbf{0 , 0 5}\end{array}$ & Kesimpulan \\
\hline 1 & 32 & 0.1562 & 0.1566 & Normal \\
\hline 2 & 32 & 0.1562 & 0.1566 & Normal \\
\hline 3 & 32 & 0.1562 & 0.1566 & Normal \\
\hline 4 & 32 & 0.1529 & 0.1566 & Normal \\
\hline 5 & 16 & 0.1511 & 0.2130 & Normal \\
\hline 6 & 16 & 0.1832 & 0.2130 & Normal \\
\hline 7 & 16 & 0.1546 & 0.2130 & Normal \\
\hline 8 & 16 & 0.1591 & 0.2130 & Normal \\
\hline \multicolumn{5}{|c|}{ Keterangan : } \\
\hline \multicolumn{2}{|c|}{ Kelompok 1} & $=$ & \multicolumn{2}{|c|}{$\begin{array}{l}\text { Kelompok } \\
\text { mahasiswa yang } \\
\text { diajar dengan gaya } \\
\text { mengajar resiprokal } \\
\text { secara keseluruhan }\end{array}$} \\
\hline \multicolumn{2}{|c|}{ Kelompok 2} & $=$ & $\begin{array}{l}\text { Kelom } \\
\text { mahasi } \\
\text { diajar } \\
\text { menga } \\
\text { secara }\end{array}$ & $\begin{array}{l}\text { ok } \\
\text { wa yang } \\
\text { dengan gaya } \\
\text { eseluruhan }\end{array}$ \\
\hline \multirow{2}{*}{\multicolumn{2}{|c|}{ Kelompok 3}} & $=$ & \multicolumn{2}{|c|}{$\begin{array}{l}\text { mahasiswa yang } \\
\text { memiliki percaya diri }\end{array}$} \\
\hline & & & \multicolumn{2}{|c|}{$\begin{array}{ll}\text { tinggi } & \text { secara } \\
\text { keseluruhan } & \end{array}$} \\
\hline \multicolumn{2}{|c|}{ Kelompok 4} & $=$ & \multicolumn{2}{|c|}{ Kelompok } \\
\hline
\end{tabular}

mahasiswa yang memiliki percaya diri rendah secara keseluruhan

Kelompok $5=\begin{aligned} & \text { Kelompok } \\ & \text { mahasiswa yang }\end{aligned}$
memiliki percaya diri tinggi, diajar dengan gaya mengajar resiprokal

Kelompok $6=\begin{aligned} & \text { Kelompok } \\ & \text { mahasiswa }\end{aligned}$ yang memiliki percaya diri tinggi, diajar dengan gaya mengajar latihan

Kelompok $7=\begin{aligned} & \text { Kelompok } \\ & \text { mahasiswa yang }\end{aligned}$ memiliki percaya diri rendah, diajar dengan gaya mengajar resiprokal

Kelompok $8=$ Kelompok mahasiswa yang memiliki percaya diri rendah, diajar dengan gaya mengajar latihan

Uji homogenitas yang digunakan dalam penelitian ini adalah uji Bartlett dengan taraf signifikansi $\boldsymbol{\alpha}=0,05$. Ringkasan hasil perhitungan uji homogenitas varians masing-masing kelompok tampak pada Tabel di bawah ini.

Tabel 3. Ringkasan Hasil Perhitungan Uji Homogenitas Varians Masingmasing Kelompok Perlakuan dengan Uji Bartlett

\begin{tabular}{|c|c|c|c|c|c|}
\hline Kel. & Varians & $\begin{array}{c}\text { Varians } \\
\text { Gabungan }\end{array}$ & $\mathbf{X}_{\text {hitung }}^{2}$ & $\begin{array}{c}\mathrm{X}_{\text {tabel }}^{2} \\
\alpha=0,05\end{array}$ & Kesimpulan \\
\hline 1 & 7.3633 & \multirow{4}{*}{8.8277} & \multirow{4}{*}{0.3408} & \multirow{4}{*}{7,81} & \multirow{4}{*}{ Homogen } \\
\hline 2 & 9.7500 & & & & \\
\hline 3 & 9.4127 & & & & \\
\hline 4 & 8.7846 & & & & \\
\hline \multicolumn{6}{|c|}{ Keterangan : } \\
\hline \multirow[t]{3}{*}{ Kel } & mpok 1 & \multirow[t]{2}{*}{$=$} & ipok & & \\
\hline & & & siswa & yang & \\
\hline & & men & liki per & ya diri & \\
\hline
\end{tabular}




\begin{aligned} & \multicolumn{2}{l}{ tinggi diajar dengan } \\ & gaya mengajar \\ Kelompok 2 $= &$ Kelompok \\ & mahasiswa yang \\ & memiliki percaya diri \\ & tinggi diajar dengan \\ & gaya mengajar \\ & latihan \\ $= &$ Kelompok \\ & mahasiswa yang \\ & memiliki percaya diri \\ & rendah diajar dengan \\ & gaya mengajar \\ & resiprokal \\ $= &$ Kelompok \\ & mahasiswa yang \\ Kelompok 4 memiliki percaya diri & rendah diajar dengan \\ & gaya mengajar \\ & latihan \end{aligned}

Dari hasil perhitungan uji homogenitas seperti tampak pada tabel di atas, didapat harga Chikuadrat sebesar $\left(\mathrm{X}_{\mathrm{h}}^{2}=0.3408\right)$ untuk seluruh kelompok sampel, lebih kecil daripada Chikuadrat tabel $\left(\chi_{t}^{2}=7,81\right)$. Dengan demikian dapat disimpulkan bahwa sampel penelitian berasal dari populasi berdistribusi homogen.

\section{Tabel 4. Rangkuman Uji} Homogenitas Secara Keseluruhan

\begin{tabular}{|c|c|c|c|c|}
\hline Kel & Var & $\mathbf{F}_{\mathbf{o}}$ & $\begin{array}{l}F_{t} \\
\alpha=0,05\end{array}$ & Kesimpulan \\
\hline $\begin{array}{l}\mathbf{A}_{1} \\
\mathbf{A}_{2}\end{array}$ & $\begin{array}{l}8.30 \\
8.97 \\
\end{array}$ & 0.93 & 1.86 & Homogen \\
\hline $\begin{array}{l}\mathbf{B}_{1} \\
\mathbf{B}_{2} \\
\end{array}$ & $\begin{array}{l}20.43 \\
12.25 \\
\end{array}$ & 1.67 & 1.86 & Homogen \\
\hline $\begin{array}{l}\mathbf{A}_{\mathbf{1}} \mathbf{B}_{1} \\
\mathbf{A}_{\mathbf{2}} \mathbf{B}_{1}\end{array}$ & $\begin{array}{l}9.75 \\
7.36 \\
\end{array}$ & 1.32 & 2.41 & Homogen \\
\hline $\begin{array}{l}\mathbf{A}_{1} \mathbf{B}_{2} \\
\mathbf{A}_{2} \mathbf{B}_{2}\end{array}$ & $\begin{array}{l}8.78 \\
9.41 \\
\end{array}$ & 0.93 & 2.41 & Homogen \\
\hline
\end{tabular}

\begin{aligned} & \multicolumn{2}{|c|}{ Keterangan : } \\ & $\mathbf{A}_{\mathbf{1}}=$ Kelompok mahasiswa yang \\ & diajar dengan gaya mengajar \\ & resiprokal \\ & $\mathbf{A}_{2}= \begin{array}{l}\text { Kelompok mahasiswa yang } \\ \text { diajar dengan gaya mengajar }\end{array} \\ &$ latihan \\ & $\mathbf{B}_{1}=$ Kelompok mahasiswa yang \end{aligned}

memiliki percaya diri tinggi secara keseluruhan

$\mathbf{B}_{2} \quad=\quad$ Kelompok mahasiswa yang memiliki percaya diri rendah secara keseluruhan

$\mathbf{A}_{\mathbf{1}} \mathbf{B}_{\mathbf{1}}=$ Kelompok mahasiswa yang memiliki percaya diri tinggi diajar dengan gaya mengajar resiprokal

$\mathbf{A}_{2} \mathbf{B}_{1}=$ Kelompok mahasiswa yang memiliki percaya diri tinggi diajar dengan gaya mengajar latihan

$\mathbf{A}_{1} \mathbf{B}_{2}=$ Kelompok mahasiswa yang memiliki percaya diri rendah diajar dengan gaya mengajar resiprokal

$\mathbf{A}_{2} \mathbf{B}_{2}=$ Kelompok mahasiswa yang memiliki percaya diri rendah diajar dengan gaya mengajar latihan.

Berdasarkan hasil perhitungan uji homogenitas varians sebagaimana terlihat pada Tabel di atas, diperoleh harga-harga $\mathrm{F}_{\text {hitung }}$ sebagai berikut:

kelompok pertama $\mathrm{F}_{\text {hitung }}=0.93$; kelompok kedua $\mathrm{F}_{\text {hitung }}=1.67$; kelompok ketiga $\mathrm{F}_{\text {hitung }}=1.32$; kelompok keempat $\mathrm{F}_{\text {hitung }}=0.93$, sedangkan $\mathrm{F}_{\text {tabel }}=1.86$ untuk yang pertama dan kedua, $\mathrm{F}_{\text {tabel }}=$ 2.41 untuk kelompok ketiga dan ke empat. Dengan demikian $F_{\text {hitung }}$ semua kelompok lebih kecil dari pada $F_{\text {tabel }}$ $\left(\mathrm{F}_{1234}<\mathrm{F}_{\text {tabe }} \mathrm{l}\right)$.

Kesimpulan, tidak terdapat perbedaan varians antara kelompok $A_{1}$ dengan $A_{2}$, antara kelompok $B_{1}$ dengan $B_{2}$, antara kelompok $A_{1} B_{1}$ dengan $A_{2} B_{1}$, dan antara kelompok $A_{1} B_{2}$ dengan $A_{2} B_{2}$. Dengan kata lain sampel berasal dari populasi yang homogen.

Setelah uji persyaratan analisis terpenuhi, selanjutnya dilakukan pengujian hipotesis statistik dengan menggunakan Analisis Varians (ANAVA) dua jalur, pada taraf signifikansi $\alpha=0,05$, dilanjutkan dengan uji Tukey. Analisis varians dua jalur ini digunakan untuk menguji pengaruh utama (main effect) dan interaksi (interaction effect) variabel bebas gaya mengajar dan percaya diri mahasiswa 
terhadap variabel terikat hasil belajar handspring. Selanjutnya rangkuman hasil perhitungan analisis data dengan ANAVA dua jalur dapat dilihat pada Tabel di bawah ini.

Tabel 5. Rangkuman Hasil Perhitungan Analisis Varians (ANAVA) Dua jalur Data Hasil Belajar Stut Senam Lantai.

\begin{tabular}{|c|c|c|c|c|c|}
\hline $\begin{array}{l}\text { SUMBER } \\
\text { VARIANS }\end{array}$ & JK & DB & RK & $\mathbf{F}_{\text {hitung }}$ & $\begin{array}{c}\mathbf{F}_{\text {tabel }} \\
\alpha=0,05\end{array}$ \\
\hline $\begin{array}{c}\text { Antar } \\
\text { Baris (b) } \\
\text { Antar } \\
\text { Kolom (k) } \\
\text { Interaksi } \\
\text { (b x k) } \\
\text { Dalam } \\
\text { Kelompok } \\
\text { (DK) }\end{array}$ & $\begin{array}{c}1899.736 \\
27.970 \\
182 \\
529.6594\end{array}$ & $\begin{array}{c}1 \\
1 \\
1 \\
60\end{array}$ & $\begin{array}{c}28.64 \\
27.97 \\
181.99 \\
6.8277\end{array}$ & $\begin{array}{c}4.19 \\
4.10 \\
26.65 \\
-\end{array}$ & $\begin{array}{c}4.00 \\
4.00 \\
4.00 \\
-\end{array}$ \\
\hline Total & 581.51 & 63 & - & - & - \\
\hline
\end{tabular}

Keterangan :

A = Gaya Mengajar Resiprokal dengan Gaya Mengajar Latihan

$\mathrm{B}=$ Percaya Diri Tinggi dengan Percaya Diri Rendah

$\mathrm{AB}=$ Interaksi antara Gaya

Mengajar dengan Percaya Diri

$\mathrm{DB}=$ Derajat bebas

RK = Rerata Kelompok

$\mathrm{F}_{\text {hitung }}=$ Harga $\mathrm{F}$ hitung

$\mathrm{F}_{\text {tabel }}=$ Harga $\mathrm{F}$ tabel

Ringkasan perhitungan tahap lanjut dengan teknik analisis Uji Tukey, tampak pada Tabel di bawah ini.
Tabel 6. Ringkasan Hasil Perhitungan Analisis Tahap Lanjut dengan Uji

Tukey

\begin{tabular}{|c|c|c|c|c|}
\hline No & $\begin{array}{c}\text { Kelompok } \\
\text { Yang } \\
\text { Dibandingkan } \\
\end{array}$ & $\mathbf{Q}_{\text {hitung }}$ & $\mathbf{Q}_{\text {tabel }}$ & Keterangan \\
\hline 1 & $\begin{array}{c}\text { G.M } \\
\text { Resiprokal } \\
\text { dengan G.M } \\
\text { Latihan } \\
\text { terhadap PD } \\
\text { tinggi } \\
\end{array}$ & 4.149 & 3.63 & Signifikan \\
\hline 2 & $\begin{array}{c}\text { G.M } \\
\text { Resiprokal } \\
\text { dengan G.M } \\
\text { Latihan } \\
\text { terhadap PD } \\
\text { rendah }\end{array}$ & 7.379 & 3.63 & Signifikan \\
\hline
\end{tabular}

\section{PEMBAHASAN}

Berdasarkan hasil perhitungan Analisis Varians (ANAVA) dua jalan dan Uji Tukey di atas maka dapat disimpulkan sebagai berikut :

1. Terdapat Perbedaan Hasil Belajar Handspring Antara yang Diajar dengan Gaya Mengajar Resiprokal dan yang Diajar dengan Gaya Mengajar Latihan Secara Keseluruhan.

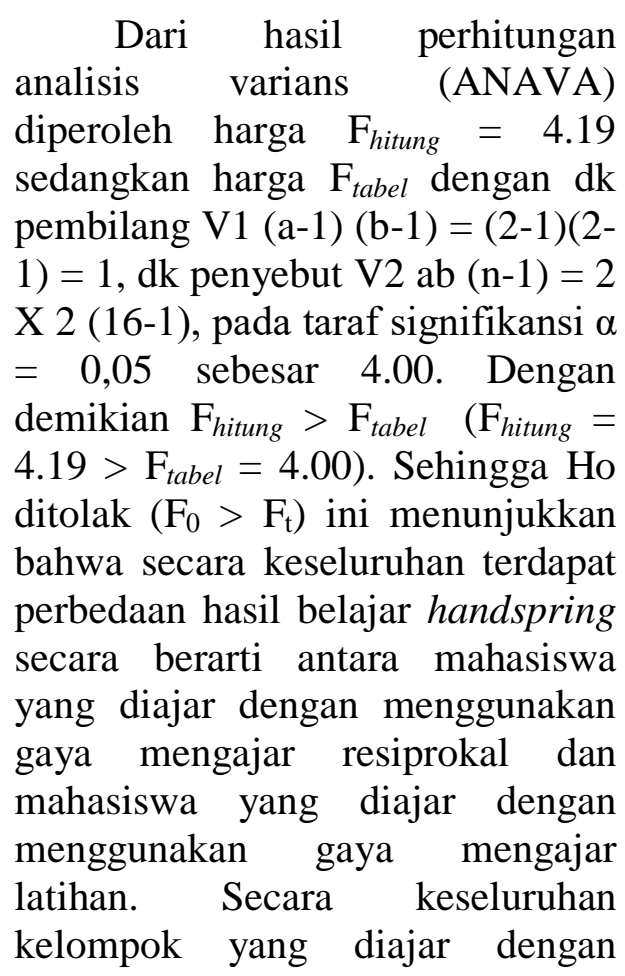


menggunakan gaya mengajar resiprokal lebih baik dibandingkan dengan kelompok yang diajar dengan menggunakan gaya mengajar latihan. Hal ini karena skor rerata kelompok gaya mengajar resiprokal adalah $\bar{X}=$ 5.50 dan $S d=2.88$ sedangkan rerata skor kelompok gaya mengajar latihan adalah $\bar{X}=5.53$ dan $S d=3.00$.

\section{Terdapat Interaksi antara} Gaya Mengajar dan Percaya Diri terhadap Hasil Belajar Handspring Senam Lantai.

\begin{tabular}{llr}
\multicolumn{1}{c}{ Dari } & hasil & perhitungan \\
analisis & varians & (ANAVA) \\
diperoleh & harga & $\mathrm{F}_{\text {hitung }}=4.10$
\end{tabular}
sedangkan harga $\mathrm{F}_{\text {tabel }}$ dengan $\mathrm{dk}$ pembilang V1 (a-1) (b-1) = (2-1) (21) $=1$, dk penyebut V2 ab (n-1) = 2 X 2 (10-1), pada taraf signifikansi $\alpha$ $=0,05$ sebesar 4.00. Dengan demikian $\mathrm{F}_{\text {hitung }}>\mathrm{F}_{\text {tabel }}\left(\mathrm{F}_{\text {hitung }}=\right.$ $\left.4.10>\mathrm{F}_{\text {tabel }}=4.00\right)$. Sehingga Ho ditolak $\left(\mathrm{F}_{0}>\mathrm{F}_{\mathrm{t}}\right)$ ini artinya terdapat pengaruh interaksi yang sangat berarti antara gaya mengajar dan percaya diri yang dimiliki mahasiswa terhadap hasil belajar handspring senam lantai.

\section{Perbedaan Hasil Belajar Handspring antara Kelompok Mahasiswa yang Diajar dengan Gaya Mengajar Resiprokal dan yang Diajar dengan Gaya Mengajar Latihan, Bagi Mahasiswa yang Memiliki Percaya Diri Tingggi}

Ditinjau dari data penelitian menggunakan uji Tukey di atas diperoleh $Q_{\text {hitung }}=4.149$ lebih besar dari pada $\mathrm{Q}_{\text {tabel }}=3.63\left(\mathrm{Q}_{\text {hitung }}=\right.$ $4.149>\mathrm{Q}_{\text {tabel }}=3.63$ ) sehingga Ho ditolak $\left(\mathrm{F}_{0}>\mathrm{F}_{\mathrm{t}}\right)$, ini berarti perbedaan yang signifikan hasil belajar Handspring bagi mahasiswa yang memiliki percaya diri tinggi yang diajar dengan gaya mengajar resiprokal dan yang diajar dengan gaya mengajar latihan. Artinya terdapat perbedaan yang sangat berarti hasil belajar handspring antara mahasiswa yang diajar dengan gaya mengajar resiprokal dan yang diajar dengan gaya mengajar latihan, bagi mahasiswa yang memiliki percaya diri tinggi. Gaya mengajar resiprokal ( $\bar{X}=5.93, S d=2.17$ ) lebih baik daripada gaya mengajar latihan $(\bar{X}=5.58, \quad S d=3.12)$ bagi mahasiswa yang memiliki percaya diri tinggi.

4. Perbedaan Hasil Belajar Handspring antara Kelompok Mahasiswa yang Diajar dengan Gaya Mengajar Resiprokal dan yang Diajar dengan Gaya Mengajar Latihan, Bagi Mahasiswa yang Memiliki Percaya Diri Rendah

Ditinjau dari data penelitian menggunakan uji Tukey di atas diperoleh $\mathrm{Q}$ hitung $=7.379$ lebih besar dari pada $\mathrm{Q}_{\text {tabel }}=3.63(\mathrm{Q}$ hitung $=7.379>\mathrm{Q}_{\text {tabel }}=3.63$ ). Sehingga Ho ditolak (F0 > Ft), ini berarti terdapat perbedaan yang signifikan hasil belajar Handspring bagi mahasiswa yang memiliki percaya diri rendah yang diajar dengan gaya mengajar resiprokal dan yang diajar dengan gaya mengajar latihan. Artinya terdapat perbedaan yang sangat berarti hasil belajar handspring antara mahasiswa yang diajar dengan gaya mengajar resiprokal dan yang diajar dengan gaya mengajar latihan, bagi mahasiswa yang memiliki percaya diri rendah. Gaya mengajar latihan 
$(\bar{X}=5.49, S d=2.96)$ lebih baik daripada gaya mengajar resiprokal $(\bar{X}=5.08, \quad S d=3.07)$ bagi mahasiswa yang memiliki percaya diri rendah.

\section{KESIMPULAN DAN SARAN}

Dari hasil pengolahan dan
analisis data sertar pengujian
hipotesis sebagaimana $r$ telah
dipaparkan, diperoleh beberapa
kesimpulan hasil penelitian sebagai
berikut:

1. Secara keseluruhan terdapat perbedaan yang berarti antara kelompok yang diajar dengan gaya mengajar resiprokal dan yang diajar dengan gaya mengajar latihan terhadap hasil belajar handspring senam lantai. Kelompok yang diajar dengan gaya mengajar resiprokal lebih baik daripada kelompok yang diajar dengan gaya mengajar latihan $\left(\mathrm{F}_{\text {hitung }}=0.93>\mathrm{F}_{\text {tabel }}=\right.$ 1.86). Dengan kata lain, secara keseluruhan gaya mengajar resiprokal memberikan pengaruh yang lebih baik daripada gaya mengajar latihan terhadap hasil belajar handspring senam lantai mahasiswa yang mengontrak mata kuliah senam lantai PJKR Universitas Siliwangi Kota Tasikmalaya. Kesimpulan dari hasil penelitian ini sesuai dengan rumusan hipotesis yang diajukan, yaitu secara keseluruhan gaya mengajar resiprokal memberikan pengaruh yang lebih baik daripada gaya mengajar latihan terhadap hasil belajar handspring mahasiswa PJKR Universitas Siliwangi Kota Tasikmalaya. Hasil penelitian ini juga selaras dengan pendapat Mosston, yang menyatakan bahwa pembelajaran dengan gaya mengajar resiprokal mencapai kepatuhan peserta didik sehingga proses pembelajaran bisa berjalan dengan lancar, mencapai keseragaman, menanamkan prosedur keselamatan sehingga proses pembelajaran berjalan dengan aman dan lancar dan berdampak pada makin efektifnya perolehan hasil belajar mahasiswa.

2. Terdapat interaksi antara gaya mengajar dengan percaya diri terhadap hasil belajar handspring senam lantai. Hal ini terlihat dari hasil perhitungan ANAVA, diperoleh $\mathrm{F}_{\text {hitung }}=6,5253$ lebih besar daripada $\mathrm{F}_{\text {tabel }}=4,11$. Ini berarti bahwa hasil belajar handspring dipengaruhi oleh gaya mengajar yang digunakan dan percaya diri, atau dengan kata lain hasil belajar handspring senam lantai, selain ditentukan oleh gaya mengajar yang digunakan, juga dipengaruhi oleh tingkat percaya diri yang dimiliki.

3. Terdapat perbedaan yang berarti antara yang diajar dengan gaya mengajar resiprokal dan yang diajar dengan gaya mengajar latihan bagi mahasiswa yang memiliki percaya diri tinggi terhadap hasil belajar handspring senam lantai. Bagi mahasiswa yang memiliki percaya diri tinggi, diajar dengan gaya mengajar latihan lebih baik daripada diajar dengan gaya mengajar resiprokal ( q $_{\text {hitung }}=$ $\left.4.149>\mathrm{q}_{\text {tabel }}=3.63\right)$. Dengan kata lain, bagi mahasiswa yang memiliki percaya diri tinggi, gaya mengajar resiprokal memberikan pengaruh yang lebih baik daripada gaya mengajar 
latihan terhadap hasil belajar handspring senam lantai mahasiswa yang mengontrak mata kuliah senam lantai PJKR Universitas Siliwangi Kota Tasikmalaya. Kesimpulan dari hasil penelitian ini sesuai dengan rumusan hipotesis yang diajukan, yaitu bagi mahasiswa yang memiliki percaya diri tinggi, gaya mengajar resiprokal memberikan pengaruh yang lebih baik daripada gaya mengajar latihan terhadap hasil belajar handspring senam lantai mahasiswa PJKR Universitas Siliwangi Kota Tasikmalaya.

4. Terdapat perbedaan yang berarti antara yang diajar dengan gaya mengajar resiprokal dan yang diajar dengan gaya mengajar latihan bagi mahasiswa yang memiliki percaya diri rendah terhadap hasil belajar handspring senam lantai. Bagi mahasiswa yang memiliki percaya diri rendah, diajar dengan gaya mengajar latihan lebih baik daripada diajar dengan gaya mengajar resiprokal ( $\mathrm{q}_{\text {hitung }}=$ $7.379>\mathrm{q}_{\text {tabel }}=3.63$ ). Dengan kata lain, bagi mahasiswa yang memiliki percaya diri rendah, gaya mengajar latihan memberikan pengaruh yang lebih baik daripada gaya mengajar resiprokal terhadap hasil belajar handspring pada mahasiswa yang mengontrak mata kuliah senam lantai PJKR Universitas Siliwangi Kota Tasikmalaya. Kesimpulan dari hasil penelitian ini sesuai dengan rumusan hipotesis yang diajukan, yaitu bagi mahasiswa yang memiliki percaya diri rendah, gaya mengajar latihan memberikan pengaruh yang lebih baik daripada gaya mengajar resiprokal terhadap hasil belajar handspring mahasiswa PJKR Universitas Siliwangi Kota Tasikmalaya.

Persoalan mendasar yang sering ditemukan dalam proses pembelajaran gerak, baik di lingkungan formal maupun non formal adalah peningkatan efektivitas pembelajaran dan latihan. Hal itu didorong oleh keinginan para orang tua mahasiswa, pengelola atau para penggemar olahraga yang semakin meningkat untuk mencapai tujuan yang diharapkan, yakni hasil belajar yang lebih baik. Efektivitas pembelajaran, dan kualitas pelajaran itu sendiri erat kaitannya dengan penguasaan pengetahuan dan keterampilan menerapkan teori-teori belajar dan hasil penelitian ke dalam kondisi pembelajaran yang sebenarnya. Oleh karena itu implikasi dari hasil penelitian ini, baik terhadap dampak teoretis maupun penerapan praktis menjadi lebih bermakna. Hasil penelitian ini memberikan implikasi terutama berkenaan dengan gaya pembelajaran untuk senam lantai khususnya pembelajaran handspring dan pendidikan di perguruan tinggi pada umumnya.

a. Kesimpulan yang menyatakan terdapat perbedaan yang berarti antara kelompok yang diajar dengan gaya mengajar resiprokal dan yang diajar dengan gaya mengajar latihan terhadap hasil belajar handspring senam lantai. Gaya mengajar resiprokal memberikan pengaruh lebih baik daripada gaya mengajar latihan terhadap hasil belajar handspring senam lantai. Oleh karena itu, khususnya bagi para tenaga pengajar atau dosen 
olahraga menyadari bahwa pemilihan gaya mengajar dalam proses pembelajaran perlu diperhatikan. Terutama dalam pembelajaran senam lantai, pemilihan gaya mengajar harus selektif karena akan berpengaruh terhadap pencapaian tujuan yang diharapkan khususnya dalam penguasaan teknik-teknik dalam senam lantai. Temuan bahwa gaya mengajar resiprokal memberikan hasil belajar handspring lebih baik dari pada gaya mengajar latihan, memberikan isyarat bahwa dalam pembelajaran handspring, strategi pembelajaran dengan menggunakan gaya mengajar resiprokal lebih cocok untuk diterapkan daripada gaya mengajar latihan. Penerapan gaya mengajar resiprokal dalam pembelajaran handspring berimplikasi terhadap perencanaan dan pengembangan strategi pembelajaran handspring senam lantai. Hal tersebut meliputi : perencanaan pembelajaran, pengelolaan kegiatan pembelajaran, desain struktur materi, dan penilaian.

Pertama, perencanaan pembelajaran harus dibuat dengan desain yang dapat mendukung terlaksananya kegiatan pembelajaran handspring dengan menggunakan gaya mengajar resiprokal. Dalam gaya mengajar resiprokal, kegiatan belajar mahasiswa cenderung kompak dan seragam serta disiplin tinggi. Setiap mahasiswa diwajibkan memahami kegiatan belajarnya melalui petunjuk dosen yang dimuat dalam bentuk lembar kerja/lembar tugas (work sheet). Atas dasar lembar kerja itu pula setiap mahasiswa diwajibkan memberikan koreksi/umpan balik kepada teman sebaya. Hal ini membawa implikasi kepada dosen akan pentingnya membuat lembar kerja/lembar tugas (work sheet) dalam setiap kegiatan pembelajarannya.

Kedua, desain pengelolaan kegiatan pembelajaran harus disusun dengan struktur yang dapat mendukung pelaksanaan gaya mengajar resiprokal. Struktur pengelolaan kegiatan pembelajaran yang dapat mendukung gaya mengajar resiprokal adalah pendekatan mengajar yang paling bergantung pada guru. Dalam gaya mengajar resiprokal masing-masing pasangan atau kelompok mahasiswa memahami dan mencoba tugastugas gerak yang terdapat dalam lembar kerja (work sheet) yang telah dipersiapkan dosen. Dengan demikian para mahasiswa akan termotivasi untuk belajar bersungguhsungguh agar bisa saling memberikan umpan balik, sehingga pada gilirannya dapat meningkatkan hasil belajar mahasiswa.

Ketiga, desain struktur materi. Struktur materi perlu disusun dengan desain yang memungkinkan para mahasiswa lebih banyak bekerjasama untuk mencapai tujuan. Untuk itu materi disusun dalam bentuk langkah-langkah (prosedur) pelaksanaan gerak handspring secara sistimatis pada lembar kerja mahasiswa yang relevan. Melalui struktur materi seperti 
itu, memungkinkan mahasiswa untuk terlibat aktif untuk melaksanakan tugas gerak yang diberikan untuk mencapai tujuan pembelajaran.

Keempat, penilaian. Penilaian atau koreksi dan umpan balik didasarkan atas hasil pengamatan dosen selama proses pembelajaran. Melalui model penilaian seperti ini diharapkan mahasiswa tidak melakukan kesalahan-kesalahan gerak secara berulang-ulang yang dapat mengakibatkan terjadinya bad habit (kebiasaan buruk), karena setiap kesalahan dapat dideteksi sedini mungkin. Model penilaian seperti ini juga dapat memotivasi mahasiswa untuk berprestasi, karena nilai yang baik hanya mungkin diperoleh jika individu bekerja keras dan berprestasi lebih baik dari pada prestasi sebelumnya.

b. Kesimpulan yang menyatakan terdapat interaksi yang berarti antara gaya mengajar dan percaya diri terhadap hasil belajar handspring senam lantai. Gaya mengajar yang digunakan akan memberikan pengaruh terhadap pencapaian tujuan yang diharapkan, karena dalam gaya mengajar terdapat hal-hal yang harus diperhatikan, seperti : keputusan sebelum pelaksanaan pembelajaran (pre impact), keputusan saat pelaksanaan pembelajaran (impact) dan keputusan setelah pelaksanaan pembelajaran (post impact). Selain gaya mengajar, percaya diri mahasiswa juga sangat berpengaruh terhadap tercapainya tujuan pembelajaran. Terutama dalam pembelajaran yang bersifat praktis, tinggi rendahnya percaya diri sangat mendukung. Dalam tercapainya keterampilan gerak atau penguasaan terhadap salah satu teknik cabang olahraga khususnya senam lantai. Upaya penerapan gaya mengajar menuntut perubahan peran dosen, khususnya dalam cara pandang terhadap mahasiswa, perlakuan terhadap mahasiswa, dan orientasi pembelajaran. Pemilihan Gaya mengajar sangat erat kaitannya dengan bagaimana cara dosen memperlakukan mahasiswa dalam proses pembelajaran. Baik itu dalam memberikan tranformasi ilmu menuntun bagaimana mahasiswa berperilaku aktif, kreatif dan kritis dalam pengembangan potensi diri mahasiswa. Sehingga implikasinya terhadap seorang tenaga pengajar atau dosen dalam mempersiapkan gaya mengajar yang akan digunakan untuk menghadapi mahasiswa yang beragam kemampuan dan keinginan, agar tujuan pembelajaran yang diharapakan bisa tercapai. Begitu juga dengan percaya diri menjadi tolak ukur keberhasilan pembelajaran dalam penguasaan keterampilan atau teknik dalam senam lantai khususnya teknik dasar handspring. Implikasinya bagi para tenaga pengajar atau dosen olahraga harus sadar dan mampu memperhatikan terlebih dahulu tingkat percaya diri mahasiswanya. Sehingga pada akhirnya nanti akan berhubungan dengan pemilihan gaya mengajar yang akan 
digunakan untuk keberhasilan proses dan hasil pembelajaran.

c. Kesimpulan yang menyatakan terdapat perbedaan pengaruh antara gaya mengajar resiprokal dan gaya mengajar latihan bagi kelompok mahasiswa yang memiliki percaya diri tinggi terhadap hasil belajar handspring senam lantai. Gaya mengajar resiprokal lebih berpengaruh terhadap hasil belajar handspring dibandingkan gaya mengajar latihan bagi mahasiswa yang memiliki percaya diri tinggi. Percaya diri tinggi ternyata memberi pengaruh lebih baik terhadap hasil belajar handspring untuk gaya mengajar resiprokal. Temuan ini mengindikasikan perlunya upaya pemilihan mahasiswa peserta pembelajaran handspring berdasarkan percaya dirinya. Pemilihan mahasiswa berdasarkan percaya diri tersebut digunakan sebagai pedoman untuk memilih dan menetapkan gaya mengajar yang tepat untuk masingmasing kelompok mahasiswa, agar diperoleh hasil belajar yang lebih optimal. Bagi mahasiswa yang memiliki percaya diri tinggi diupayakan penerapan gaya mengajar resiprokal pada pembelajaran handspring, karena sesuai dengan karakteristiknya gaya mengajar resiprokal lebih memberikan keleluasaan kepada mahasiswa untuk mengembangkan dan mengeksplor kemampuan yang dimiliki, sehingga dalam proses belajar dapat meningkatkan daya saing dalam mempelajari tugas ajar dan memberi kesempatan untuk berkreatif dan memanfaatkan waktu untuk mencapai penguasaan gerak sehingga pembelajaran lebih menantang. Maka dari itu bagi mahasiswa yang memiliki percaya diri tinggi, gaya mengajar resiprokal lebih baik digunakan dalam pencapaian hasil belajar handspring senam lantai.

d. Kesimpulan yang menyatakan terdapat perbedaan pengaruh antara gaya mengajar resiprokal dan gaya mengajar latihan bagi kelompok mahasiswa yang memiliki percaya diri rendah terhadap hasil belajar handspring. Gaya mengajar latihan lebih baik daripada gaya mengajar resiprokal terhadap hasil belajar handspring bagi mahasiswa yang memiliki percaya diri rendah. Gaya mengajar latihan lebih berpengaruh baik terhadap mahasiswa yang memiliki percaya diri rendah terhadap hasil belajar handspring. Itu karena mahasiswa yang memiliki percaya diri rendah lebih bersifat pasif, malas dan kurang kreatif sehingga dibutuhkan suatu pembalajaran yang benar-benar terkontrol dan terkendali agar proses dan hasilnya bisa tercapai optimal. Gaya mengajar latihan lebih cocok dan pantas bagi mahasiswa yang memiliki percaya diri rendah, karena karakteristik gaya ini adalah semua kendali ada pada tenaga pengajar atau dosen, mempertinggi kedisiplinan dan kepatuhan, sangat efektif dan efisien untuk waktu yang 
singkat, dan juga baik untuk membina keseragaman dan kekompakan. Maka dari itu dalam optimalisasi hasil pembelajaran seorang tenaga pengajar atau dosen perlu untuk mempersiapkan dan memilih gaya pembelajaran yang sesuai dengan kemampuan peserta didiknya.

\section{DAFTAR PUSTAKA}

Frank M. Ferducci, Measurement Concepta in Physical Education.

St.Louis Missouri: Mosby Company, 1980.

Halim Susilodinata.,dan Agus Mukholid. Teaching Physical Education By

Muska Mosston. Jakarta: Pascasarjana IKIP Jakarta, 1994.

Mosston, M. Teaching Physical Education First Online Edition, New York Mac Millan College Publishing Inc, 1994.

Hidayat, Cucu. Psikologi Olahraga. Tasikmalaya: PJKR UNSIL, 2008.

Hidayat, Imam. Senam, Bandung. Fakultas Pendidikan Olahraga dan Kesehatan Universitas Pendidikan Indonesia, 1996.

Husdarta, H.J.S. Psikologi olahraga.Bandung: Alfabeta, 2010.

Komaruddin, psikologi Olahraga. Bandung: PT Remaja Rosdakarya, 2013

Lutan, Rusli. Belajar Keterampilan Motorik: Pengantar Teori dan Metode.
Jakarta, Depdikbud, 1988.

Mahendra, Agus. Teori Dan Metode Pembelajaran Senam. Bandung

Fakultas Pendidikan Olahraga dan Kesehatan Universitas

Pendidikan Indonesia,2004.

Matakupan, J. Strategi Belajar Mengajar. Jakarta: Dinas P dan K DKI

Jakarta,1991/1992.

Nasution, S. Berbagai Pendekatan dalam Proses Belajar dan Mengajar. Jakarta: Bumi Aksara, 2008.

Purwanto,Ngalim. Psikologi Pendidikan. Bandung: Remaja Rosdakarya, 2007

Purwanto. Evaluasi Hasil Belajar. Yogyakarta: Pustaka Pelajar: 2011.

Sudjana. Metode Statistika. Bandung: Tarsito, 1992.

Suprijono, Agus. cooperative learning. Yogyakarta: Pustaka Pelajar, 2012.

Slameto. Belajar dan faktor-faktor yang mempengaruhinya. Jakarta:

Rineka Cipta, 2010.

Tangkudung, James. Kepelatihan Olahraga, Pembinaan Prestasi

Olahraga. Jakarta: Penerbit Cerdas Jaya 2012.

Walgito, Bimo. Pengantar Psikologi Umum. Yogyakarta: Andi, 2004. Winkel, W.S. Psikologi Pengajaran. Jakarta: PT. Grasindo, 1991. 